\title{
The Prevalence of Needlestick Injuries and Exposure to Blood and Body Fluids Among Iranian Healthcare Workers: A Systematic Review
}

\author{
Zhila Fereidouni ${ }^{1}$, Morteza Kameli Morandini ${ }^{2}$, Azizallah Dehghan ${ }^{3}$, Nahid Jamshidi ${ }^{4}$, Majid Najafi Kalyani ${ }^{*}$ \\ ${ }^{1}$ School of Nursing, Fasa University of Medical Sciences, Fasa, Iran \\ ${ }^{2}$ Department of Nursing, Faculty of Medicine, Sari Branch, Islamic Azad University, Sari, Iran \\ ${ }^{3}$ Noncommunicable Diseases Research Center, Fasa University of Medical Sciences, Fasa, Iran \\ ${ }^{4}$ Student Research Committee, School of Nursing and Midwifery, Shiraz University of Medical Sciences, Shiraz, Iran \\ ${ }^{5}$ School of Nursing and Midwifery, Shiraz University of Medical Sciences, Shiraz, Iran
}

Corresponding Author: Majid Najafi Kalyani, PhD, Assistant Professor, School of Nursing and Midwifery, Shiraz University of Medical Sciences, Shiraz, Iran. Tel: +98-7136474254, Email: majidnajafi5@yahoo.com

Received February 2, 2018; Accepted February 28, 2018; Online Published March 20, 2018

\begin{abstract}
Introduction: This study aimed to systematically review previous studies conducted in Iran on the prevalence of injuries caused by needlestick, sharp, and cutting instruments and exposure to blood and body fluids.

Methods: In this systematic review, all published full-text articles authored by Iranian researchers in Farsi or English in the field of needlestick injuries among healthcare workers during the period 2001-2016 were examined. Searches were performed on Iranian databases such as Scientific Information Database (SID), Iran Magazine Information Bank (Mag Iran), Iranian Journals of Nursing (N Index), and Directory of Medical Sciences Articles (Iran Medex) as well as international databases including Google Scholar, ISI Web of Knowledge, Scopus, PubMed, Science Direct, and CINAHL.

Results: The prevalence of injuries caused by needles ranged from $10.0 \%$ to $84.29 \%$ in different studies. The prevalence of exposure to blood and body fluids ranged from $13.46 \%$ to $79 \%$.

Conclusions: The results indicated that almost half of Iranian healthcare workers during their daily work are at the risk of needlestick injury and exposure to blood and body fluids. Hence, research and needlestick injury reduction strategies should be emphasized, and modifications should be made to organizational factors such as the development of educational programs, prevention along with performance monitoring, engineering factors such as redesigning tools to promote safety, and behavioral factors such as behavior modification of capping needles.

Keywords: Needlestick Injury, Body Fluids, Health Personnel, Iran

Citation: Fereidouni Z, Kameli Morandini M, Dehghan A, Jamshidi N, Najafi Kalyani M. The prevalence of needlestick injuries and exposure to blood and body fluids among Iranian healthcare workers: a systematic review. Int J Med Rev. 2018;5(1):35-40. doi:10.29252/ IJMR-050106.
\end{abstract}

\section{Introduction}

Injuries caused by needles and sharp and cutting objects include wounds, cuts, or abrasions caused by medical devices that may have already been contaminated with blood or other body fluids. ${ }^{1}$ In most studies on injuries caused by needles and sharp objects, the injuries are introduced as an important occupational hazard for healthcare workers. ${ }^{2,3}$ There are about thirty-five million healthcare workers in the world who make up $12 \%$ of the world labor force. ${ }^{4}$ The Center for Disease Control and Prevention estimates that 385000 healthcare workers in America annually experience injuries caused by needles and sharp objects. ${ }^{5}$ In some countries, including Iran, despite safety precautions, injuries caused by needles and sharp objects still occur, inflicting significant economic and human costs. ${ }^{6}$ More than $90 \%$ of infections caused by sharp tools among healthcare workers occur in low-income countries where these injuries are preventable. ${ }^{7,8}$ Given the necessity for a coherent review study regarding injuries caused by needles, sharp objects, blood and body fluids, the current study aimed to make an analytical review of previous research conducted in this regard to determine the prevalence of the phenomenon among Iranian healthcare workers.

\section{Methods}

This study was a systematic review of the research conducted in the field of injuries caused by needlestick, sharp objects, and exposure to blood and body fluids among Iranian healthcare workers.

Copyright (C) 2018 The Author(s). This is an open-access article distributed under the terms of the Creative Commons Attribution License (http:// creativecommons.org/licenses/by/4.0), which permits unrestricted use, distribution, and reproduction in any medium, provided the original work is properly cited. 
Search Strategy and Eligibility Criteria

In this study, a literature search strategy, selection of published studies, data extraction, and the reporting of the results of reviewed studies based on the Preferred Reporting Items for Systematic Reviews and Meta-Analyses (PRISMA) guidelines (Figure 1) were employed. In the search, the following keywords were used: Needlestick injury AND Iran (Needlestick OR Needle-stick OR Sharp Injury). Inclusion criteria were as follows: study conducted in Iran, availability of full-text article, published in Farsi or English. Selection criterion was the relevance of the study subject.

\section{Data Collection}

Articles were collected from Iranian databases such as Scientific Information Database (SID), Iran Magazine Information Bank (Mag Iran), Iranian Journals of Nursing (N Index), and Directory of Medical Sciences Articles (Iran Medex) as well as international databases including Google Scholar, ISI Web of Knowledge, Scopus, PubMed, Science Direct, and CINAHL. In searching for a comprehensive strategy, all published full-text articles authored by Iranian researchers in Farsi or English in the field of needlestick injuries among healthcare workers during the period 20012016 were examined. The findings were then tabulated, and the necessary information was extracted.

\section{Study Design}

All studies with all designs that investigated and reported the prevalence of needlestick and sharp injuries among Iranian healthcare workers were included.

\section{Data Extraction}

After the screening and selection of eligible studies, the following data was extracted: name of first author, year of publication, study design, sample size, concerned healthcare workers, and prevalence of injury.

\section{Results}

In a preliminary search based on selected keywords, 4012 articles were found. After evaluation for duplication, relevancy, accordance with research question, and abstract screening, 60 papers were checked for eligibility. Ultimately, 49 articles with relevant research topics were selected (Figure 1). As shown in Table 1, 36 articles in Farsi published in Iranian journals $(73.5 \%)^{2,3,9-12,13-42}$ and 13 articles in English published in Iranian and non-Iranian English language journals $(26.5 \%)^{11,54,65}$ were included in the study. The prevalence of injuries caused by needles ranged from $10.0 \%$ to $84.29 \%$ in different studies ${ }^{13,14}$ and a total of 52 data in 49 studies showed that on average, damage caused by needles to healthcare workers is $47.9 \% .^{2,3,9-55}$ The prevalence of exposure to blood and body fluids ranged from $13.46 \%$ to $79 \%,{ }^{25,55}$ and a combination of 7 studies showed that the mean prevalence of exposure to blood and body fluids is $46.47 \%$. ${ }^{15,25,30,37,38,54,55}$

\section{Discussion}

Injuries caused by needlestick and exposure to blood and body fluids are considered to be highly significant occupational hazards requiring special attention due to the risk of transmission of infection. This systematic review focused on the incidence of injuries caused by needlestick and exposure to blood and body fluids among healthcare workers in Iran. The results of several studies reviewed in this research showed that the prevalence of injuries caused by needles ranged from $10.0 \%$ to $84.29 \%$ and that on average, damage caused by needles among healthcare workers is $47.9 \%$. As the results indicate, the prevalence of needlestick injuries among healthcare workers in Iran is significant; almost half of all healthcare workers are affected. Given that the majority of studies conducted around the world have indicated that many health professionals do not report injuries from needlestick, ${ }^{57,56}$ the actual rate of injury caused by needlestick is probably higher than reported. The incidence of injury caused by needlestick and exposure to blood and body fluids is not expressed the same in all regions. This variability depends on economic prosperity and the health budgets of each country, the number of health staff in different therapeutic areas, different cultural and business environments, available

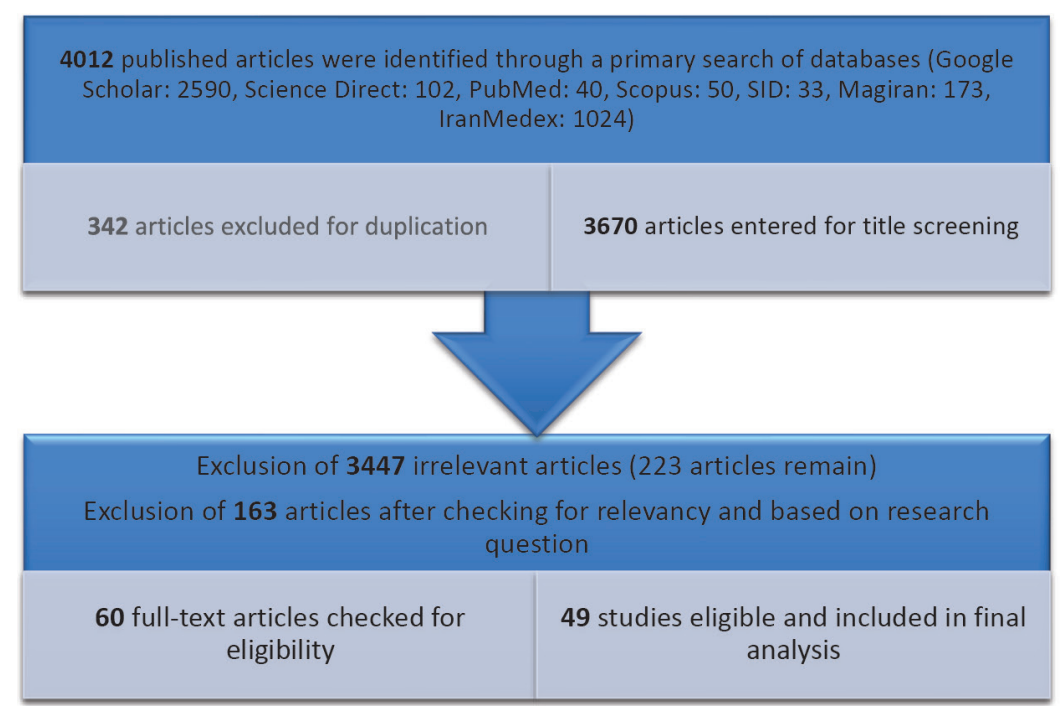

Figure 1. Flow Chart of the Study. 
Table 1. Specifications of Studies on Needlestick in Iranian Healthcare Workers

\begin{tabular}{|c|c|c|c|c|c|c|}
\hline First Author & $\begin{array}{l}\text { Publication } \\
\text { Year }\end{array}$ & Study Design & $\begin{array}{l}\text { Sample } \\
\text { Size }\end{array}$ & Concerned Personnel & $\begin{array}{l}\text { Injury } \\
\text { Prevalence }\end{array}$ & Ref. \\
\hline Balouch, A. & 2015 & Cross-sectional & 200 & Nurses & $64 \%$ & 43 \\
\hline Jahangiri, M. & 2015 & Cross-sectional & 168 & Nurses & $76 \%$ & 44 \\
\hline Adib-Hajbagheri, M. & 2013 & Cross-sectional & 298 & Nurses, midwives, laboratory technicians, nursing assistants & $38.3 \%$ & 45 \\
\hline Mahmoudi, N. & 2015 & Cross-sectional & 100 & Nurses & $41 \%$ & 46 \\
\hline Mohammadnejad, E. & 2014 & Cross-sectional & 135 & Doctors, nurses, laboratory staff & $64.4 \%$ & 47 \\
\hline Gholami, A. & 2013 & Cross-sectional & 384 & Doctors, nurses, midwives, technicians, nursing assistants, workers & $32.3 \%$ & 48 \\
\hline Farsi, D. & 2012 & Cross-sectional & 200 & $\begin{array}{l}\text { Physicians, residents, interns, nurses, laboratory technicians, service } \\
\text { workers, others }\end{array}$ & $57.5 \%$ & 49 \\
\hline Kazemi, M. H. & 2010 & Cross-sectional & 158 & Nurses & $56.96 \%$ & 50 \\
\hline Haj-Abdulbaghi, $M$. & 2014 & Cross-sectional & 358 & Nurses & $23.46 \%$ & 9 \\
\hline Hosseini, S. M. & 2013 & Cross-sectional & 214 & Nursing students & $56.3 \%$ & 10 \\
\hline Nezhad Ghaderi, SM. & 2012 & $\begin{array}{l}\text { Descriptive- } \\
\text { analytical }\end{array}$ & 186 & $\begin{array}{l}\text { Nurses, auxiliary nurses, technicians of operating room, anesthesia, } \\
\text { and laboratory }\end{array}$ & $54.1 \%$ & 11 \\
\hline Shoghli, A. & 2012 & Cross-sectional & 593 & $\begin{array}{l}\text { Nurses, auxiliary nurses, operating room personnel, midwives, } \\
\text { anesthesia personnel, laboratory personnel }\end{array}$ & $53.6 \%$ & 12 \\
\hline ParsaPili, J. & 2013 & Cross-sectional & 515 & Nurses & $18.8 \%$ & 51 \\
\hline Taghavi, R. & 2014 & Cross-sectional & 191 & $\begin{array}{l}\text { Doctors, nurses, midwives, personnel of operating room, } \\
\text { anesthesia, laboratory technicians, radiology technicians, nursing } \\
\text { assistants, technical personnel, accounting, services }\end{array}$ & $84.29 \%$ & 13 \\
\hline Zeighami, R. & 2013 & Historical cohort & 310 & Nurses & $10 \%$ & 14 \\
\hline Mirzaei, M. & 2011 & Cross-sectional & 120 & Nurses & $\begin{array}{l}71.7 \% \text { needle } \\
39.4 \% \text { blood }\end{array}$ & 15 \\
\hline Rezaei, S. H. & 2014 & Cross-sectional & 514 & $\begin{array}{l}\text { Nurses, nursing assistants, anesthetists, and operating room } \\
\text { technicians. }\end{array}$ & $26.07 \%$ & 52 \\
\hline Rezaei, S. H. & 2012 & Cross-sectional & 991 & Doctors, nurses, medical students and nurses, auxiliary nurses & $16.85 \%$ & 16 \\
\hline Rahnavard, F. & 2011 & Cross-sectional & 500 & Nurses, paramedics & $77.2 \%$ & 17 \\
\hline Hashemi, S. H. & 2011 & Cross-sectional & 700 & $\begin{array}{l}\text { Physicians, physician assistants, interns, nurses, midwives, nursing } \\
\text { and midwifery students, lab and radiology staff, nursing assistants, } \\
\text { servants }\end{array}$ & $24.1 \%$ & 18 \\
\hline Ehsani, S. R. & 2013 & Cross-sectional & 328 & Nurses & $45.12 \%$ & 53 \\
\hline Baghcheghi, N. & 2010 & Cross-sectional & 227 & Nursing students & $70 \%$ & 19 \\
\hline Heidari, M. & 2010 & Cross-sectional & 77 & $\begin{array}{l}\text { Operating room staff (surgeons, anesthetists, nurses, operating room } \\
\text { technicians, anesthesia technicians, workers, service personnel) }\end{array}$ & $74.03 \%$ & 20 \\
\hline Nouhi, E. & 2010 & Cross-sectional & 190 & Nursing and midwifery trainees and interns & $42.3 \%$ & 21 \\
\hline Abbasi, A. & 2010 & Cross-sectional & 200 & $\begin{array}{l}\text { Nursing and midwifery students after training principles and } \\
\text { techniques }\end{array}$ & $26 \%$ & 22 \\
\hline $\begin{array}{l}\text { Mohammad Nezhad, } \\
\text { E. }\end{array}$ & 2010 & Cross-sectional & 218 & Nurses and paramedics of emergency departments & $43.11 \%$ & 23 \\
\hline $\begin{array}{l}\text { Mohammad Nezhad, } \\
\text { E. }\end{array}$ & 2009 & Cross-sectional & 68 & Nurses & $47.03 \%$ & 24 \\
\hline Kouhestani, H. R. & 2010 & Cross-sectional & 52 & Medical emergencies students & $\begin{array}{l}32.7 \% \text { needle } \\
13.46 \% \text { blood }\end{array}$ & 25 \\
\hline Ghasemi, A. & 2009 & Cross-sectional & 568 & Nurses and service personnel & $55 \%$ & 26 \\
\hline Khalouee, A. & 2009 & Cross-sectional & 388 & Nurses, nursing assistants & $33 \%$ & 27 \\
\hline Seraji, A. & 2009 & Cross-sectional & 275 & Nursing and midwifery students & $43 \%$ & 29 \\
\hline Bahreini, M. & 2009 & Clinical Trial & 120 & Nurses, paramedics & $37 \%$ & 30 \\
\hline Mohammadi, N. & 2011 & $\begin{array}{l}\text { Descriptive- } \\
\text { analytical }\end{array}$ & 138 & Nurses & $\begin{array}{l}52.9 \% \text { needle } \\
65.4 \% \text { blood }\end{array}$ & 54 \\
\hline Gholami, A. & 2010 & Cross-sectional & 400 & Nurses, other health workers, service personnel & $26.8 \%$ & 31 \\
\hline Abdi, M. H. & 2008 & Cross-sectional & 298 & $\begin{array}{l}\text { Surgeons, physicians, nurses, paramedics, midwives, technicians of } \\
\text { laboratory, surgery and anesthesia }\end{array}$ & $47.3 \%$ & 32 \\
\hline Rakhshani, F. & 2007 & Cross-sectional & 231 & $\begin{array}{l}\text { Nurses, midwives, technicians of laboratory, operating room, and } \\
\text { anesthesia, nursing assistants }\end{array}$ & $64.9 \%$ & 3 \\
\hline Askarian, M. & 2005 & Cross-sectional & 1555 & Junior nurses, nurses, midwives, nursing assistants & $\begin{array}{l}50 \% \text { needle } \\
79 \% \text { blood }\end{array}$ & 55 \\
\hline
\end{tabular}


Table 1. Continued

\begin{tabular}{|c|c|c|c|c|c|c|}
\hline First Author & $\begin{array}{l}\text { Publication } \\
\text { Year }\end{array}$ & Study Design & $\begin{array}{l}\text { Sample } \\
\text { Size }\end{array}$ & Concerned Personnel & $\begin{array}{l}\text { Injury } \\
\text { Prevalence }\end{array}$ & Ref. \\
\hline Moradi, A. & 2010 & Cross-sectional & 182 & $\begin{array}{l}\text { Doctors, dentists, nurses, paramedics, midwives, laboratory } \\
\text { technicians, health workers, other health workers }\end{array}$ & $57.7 \%$ & 33 \\
\hline Joneydi Jafari, N. & 2009 & Cross-sectional & 613 & Nurses & $32.78 \%$ & 34 \\
\hline Bizhani, B. & 2010 & Cross-sectional & 172 & Nurses & $32 \%$ & 35 \\
\hline Lotfi, R. & 2006 & Cross-sectional & 90 & $\begin{array}{l}\text { Doctors, dentists, midwives, nurses, laboratory technicians, } \\
\text { anesthesia personnel and operating room staff, paramedics }\end{array}$ & $80 \%$ & 36 \\
\hline Nazmiyeh, $\mathrm{H}$. & 2005 & Cross-sectional & 1020 & $\begin{array}{l}\text { Doctors, nurses, nursing assistants, midwives, paramedics, medical } \\
\text { students, nurses, midwifery and paramedical, coaches, teachers, } \\
\text { workers, secretaries }\end{array}$ & $57.25 \%$ & 2 \\
\hline Vahedi, M. S. & 2004 & $\begin{array}{l}\text { Descriptive- } \\
\text { Analytical }\end{array}$ & 847 & Nurses, paramedics, midwives, laboratory technicians & $\begin{array}{l}64.9 \% \text { needle } \\
57.5 \% \text { blood }\end{array}$ & 37 \\
\hline Agha Doust, D. & 2005 & Cross-sectional & 678 & $\begin{array}{l}\text { Specialist physicians, general practitioners, nurses, technicians and } \\
\text { nurses of operating room, laboratory technicians, medical interns, } \\
\text { nursing interns, anesthesia technicians }\end{array}$ & $\begin{array}{l}74.3 \% \text { needle } \\
63.7 \% \text { blood }\end{array}$ & 38 \\
\hline Nasiri, E. & 2004 & Cross-sectional & 352 & $\begin{array}{l}\text { Nurses, operating room technicians, anesthesia technicians, } \\
\text { surgeons, anesthetists, paramedics }\end{array}$ & $76 \%$ & 39 \\
\hline Askarian, M. & 2005 & $\begin{array}{l}\text { Descriptive- } \\
\text { Analytical }\end{array}$ & 137 & All clinical dental students & $73.7 \%$ & 40 \\
\hline Mirzaei, T. & 2003 & Cross-sectional & 231 & Nurses, midwives, laboratory technicians, nursing aides & $46.3 \%$ & 41 \\
\hline Afrasiyabi far, A. & 2001 & Retrospective & 159 & $\begin{array}{l}\text { Nurses, operating room technicians, anesthesia technicians, } \\
\text { midwives, paramedics, laboratory workers }\end{array}$ & $39.3 \%$ & 42 \\
\hline
\end{tabular}

facilities, as well as the awareness and importance of the issue for policymakers. The lowest incidence of injuries resulting from needlestick in Iran was $10.0 \%$ reported by Zeighami et al in training hospitals in Qazvin in a historical cohort study was done on nursing staff who were responsible for direct patient care. The nurses in the case group were selected from the emergency department, and the control group consisted of nurses from other wards. Zeighami et al mentioned that the risk of needlestick injuries among nurses in emergency wards is dramatically higher than in other wards. ${ }^{14}$ The lowest prevalence in Iran was approximate to the annual mean value reported for 100 beds in Japan (5.7-6.7) and healthcare workers in Switzerland (9.7\%)..$^{59-58}$ The highest prevalence of injuries caused by needlestick, cutting, and sharp objects (84.29\%) was reported by Taghavi et al in Sina hospital in Mashhad. In this study, healthcare workers from the emergency ward, inpatient wards, operating room, radiology, labor and laboratory were examined. The researcher named possible causes such as heavy workload of healthcare workers and non-compliance of the standard number of personnel in hospital with the number of beds. ${ }^{13}$ The highest prevalence was approximate to Ilhan's reported value in Turkey (79.9\%) of staff experiencing needlestick during the course of their work. ${ }^{60}$ The wide range of the prevalence of injury among healthcare workers $(10.0 \%-84.2 \%)$ can be attributed to differences in the samples of each study (for example, in one study, only nurses were evaluated, and in another, nurses, doctors, and other healthcare providers were evaluated), types of hospital (private vs. public), ward types (emergency department vs. other departments), and study methods.

The mean prevalence of injury caused by needlestick and sharp objects for healthcare workers was $47.9 \%$. The frequencies of injuries caused by needlestick and sharp objects for healthcare workers were $9.7 \%$ and $30.8 \%$ annually in Switzerland and Ethiopia, respectively, 65\% in 5 years in Portugal, 57\% among healthcare staff in England, and 38\% during the work period last year. ${ }^{59,61-63}$ The prevalence of exposure to blood and body fluids in different studies ranged from $79 \%$ to $13.46 \%$, and the mean prevalence of exposure to blood and body fluids was $47.46 \% .^{15,25,30,37,38,54,55}$ As the results showed, exposure to blood and body fluids also affects almost half of the healthcare workers in Iran. This result was consistent with the result of a study conducted in a hospital in India, which reported the rate of exposure to blood and body fluids to be $47.14 \%{ }^{64}$

\section{Conclusions}

Important factors affecting the reduction of the incidence rate of injury include the following: emphasis on efficient research and strategies based on evidence of reduced risk of injuries caused by sharp object penetration, the provision of continuing education on the risk of diseases transmitted through blood, emphasis on observing the principles of comprehensive precautions and standards, use of newly developed technologies in the manufacture of safe medical equipment, use of the systems and experiences of other countries in the field of reporting and methods of reducing risk, observation of standards and compliance of the ratio of number of beds and patients to personnel, immunization of the environment and observation of safety principles at work, understanding and evaluation of patients during interventions, performing invasive interventions based solely on basic needs while complying with standard principles, and maintenance of mental calmness during work. One possible 
limitation of this systematic study was the possibility of the occurrence of errors while searching based on the research strategies.

\section{Authors' Contributions}

ZF was involved in the database search, extracting data, and the early drafting of the manuscript; MNK contributed to the conception and design of the study and aided in writing and revising the manuscript; NJ was involved in the conception and design of the study and the search for articles; MKM aided in the database search, extracting data, and revision of the manuscript; $\mathrm{AD}$ acted as advisor in all stages of the research.

\section{Conflict of Interest Disclosures}

The authors declare no conflicts of interest.

\section{Funding/Support}

Fasa University of Medical Sciences, Fasa, Iran supported this study.

\section{Acknowledgments}

The authors would like to thank the Deputy for Research of the Fasa University of Medical Sciences for the support given to this project.

\section{References}

1. Himmelreich $\mathrm{H}$, Rabenau HF, Rindermann M, et al. The management of needlestick injuries. Dtsch Arztebl Int. 2013;110(5):61-67. doi:10.3238/arztebl.2013.0061.

2. Nazmieh H, Najaf-Yarandi A, Janmohammadi S, Hosseini F. Assessment of the injuries caused by sharp instruments in the health workers of university hospitals, in Yazd. Iran Journal of Nursing. 2005;18(43):49-59. [Persian].

3. Rakhshani F, Heidari MT, Barati S. Prevalence of needlestick injuries among the healthcare professionals in Zahedan medical Sciences university. Iran J Epidemiol. 2009;4(3-4):87-91.

4. World Health Organization. The World Health Report. Geneva: WHO; 2002

5. Manzoor I, Daud S, Hashmi NR, et al. Needle stick injuries in nurses at a tertiary health care facility. J Ayub Med Coll Abbottabad. 2010;22(3):174-178.

6. Lee J, Botteman M, Nicklasson L. A systematic review of the economic and humanistic burden of needlestick injury in the united states. Am J Infect Control. 2004;32(3):E43. doi:10.1016/j. ajic.2004.04.064.

7. Kermode M, Jolley D, Langkham B, Thomas MS, Crofts N. Occupational exposure to blood and risk of bloodborne virus infection among health care workers in rural north Indian health care settings. Am J Infect Control. 2005;33(1):34-41. doi:10.1016/j. ajic.2004.07.015.

8. Sayehmiri K, Mohammadi E, Mohammadi I, Sayehmiri F. Epidemiology of needle sticks and sharps injuries in healthcare workers in Iran: a systematic review and meta-analysis. Iran Occupational Health Journal. 2014;11(5):93-103.

9. Hajabdolbachi M, Mohammadi Nejad E, Hadizadeh R. The epidemiologic aspects of occupational exposure in emergency nurses: A 5-years longitudinal study. Iranian Journal of Infectious Diseases. 2014;65:1-5. [Persian].

10. Hosseini Sanjadak SM, Fani maki O, Vagharseyedin SA. The prevalence of needle stick injury and associated factors in Nursing students. Journal of Health \& Care. 2014;4:30-38. [Persian].

11. Nejadghaderi $M$, Safizadeh $H$, Khanjani N. The knowledge and practice of medical staff about needle injuries in Rafsanjan's Ali-
ebne-Abitaleb hospital, Iran. J Health Dev. 2012;1(1):1-10. [Persian].

12. Shoghli A, Mousavi Nasab N, Ghorchian F, Masoumi H, Momtazi S. Study of the Needle Sticks Injury (NSI) among the Zanjan Educational Hospitals Staff. J Zanjan Univ Med Sci. 2013;21(85):131-141. [Persian].

13. Taghavi R, Tavakoli Tabasi K, Mohamadi S, Kor K. Frequency of Work Injuries of Needle Stick among Personnel in Sina Hospital in 2011. J Neyshabur Univ Med Sci. 2015;2(5):22-28. [Persian].

14. Zeighami R, Azimian J, Haghi M, Kaboodi B, Bijani B, Haghi M. A comparison between the risk of needle stick injuries among nurses in emergency wards and nurses in other wards of hospitals. Mod Care J. 2014;10(4):272-278. [Persian].

15. Mirzaei M, Khozaei S, Rezaeian Langroudi R, Zahra Z. Prevalence, causes \& practice of nursing in related to occupational exposures in Hamadan. Aflak Journal (Lorestan University of Medical Sciences, School of Nursing and Midwifery Khorramabad). 2011;24-25:2431. [Persian].

16. Rezaei S, Rabirad N, Tamizi Z, Fallahi Khoshknab M, Mohammad Nejad E, Mahmoodi M. Needle sticks injuries among heath care workers in emergency medical centers in Tehran University of Medical Sciences Hospitals (2007-2010). Journal of Health Promotion Management. 2012;1(3):46-54. [Persian].

17. Rahnavard F, Reza Masouleh S, Seyed Fazelpour SF, Kazemnejad Leili E. Study Factors related to report the needle stick and sharps injuries report by nursing staffs of the Educational and Therapeutic Centers of Guilan University of Medical Sciences, Rasht. J Holist Nurs Midwifery. 2011;21(1):30-37. [Persian].

18. Hashemi SH, Torabian S, Mamani M, Moazen Dehkordi S. The Prevalence of Needlestick and Sharps Injuries among Health Care Workers in Hamadan, Iran. Avicenna J Clin Med. 2012;18(4):41-46. [Persian].

19. Baghcheghi N, Koohestani HR, Rezaei k, Seraji A, Abedi AR. Prevalence needlestick/sharps injuries among nursing student and related factor. Iran Occupational Health Journal. 2011;7(4):31-39. [Persian].

20. Heidari $M$, Shahbazi S. Prevalence of needle sticks exposure in operation room's staff of Borujen \& Lordegan hospitals-2010-2011. Journal of School Nursing Midwifery and Allied Health. 2010;5(12):32-37. [Persian].

21. Noohi E, Khoshnood Z, Sayyed Aadel M. Needle stick and sharp object injuries among nursing \& midwifery students of Kerman University of Medical Science, 2007. Iran J Nurs Res. 2010;5(18):1823. [Persian].

22. Abbasi E, Shafipour V, Nassiri Takami GR. Knowledge, attitude and practice of nursing and midwifery students of Sari Islamic Azad University about the prevalence and ways to prevent needle stick and sharp injuries. Woman Health Quarterly Journal. 2010;1(1):105114. [Persian].

23. Mohammadi Nejad E, Esfandbod M, Ehsani SR, Deljoo R. Needlestick injuries and reporting among emergency nurses in Tehran University of Medical Science. Iranian Journal of Infectious Disease and Tropical Medicine. 2010;48(15):49-54. [Persian].

24. Mohammad Nejad E, Esfand Bod M. Epidemiologic aspects of the nurse's occupational exposure to sharp objects. Iranian Journal of Infectious Diseases and Tropical Medicine. 2009;45(14):47-50. (Persian).

25. Koohestani HR, Baghcheghi N, Rezaei K. Blood contaminated needle stick/sharp objects injuries and exposure to patients' body fluids in medical emergency students. Iran J Crit Care Nurs. 2010;3(2):57-62. [Persian].

26. Ghasemi A. Eatemad E, PourMohammad Jan N, Bashiri J, Habib Zadeh Sh. Needle stick injuries and associated factors in two groups of nurses and service workers in Hospitals of Ardabil University of Medical Sciences. Infectious and Tropical Diseases Journal. 2009;14(46):27-32. [Persian].

27. Khalouei A, Iranpour A, Hamzehnezhadi S, Rahmanian K. Study on epidemiology of needle stick injury among nursing personnel of Kerman University hospitals. Kerman, Iran in (2006-2007). Jahrom Medical Journal. 2010;7(3):43-51. [Persian].

28. Ghorbani GA. [Prevalence of occupational blood transmitted viral 
infection in health care workers after needle stick and sharp injury]. Kowsar Medical Journal. 2010;14(4):223-228. [Persian].

29. Seraji A, Koohestani H, Baghcheghi N, Rezaei K. Barriers to the Reporting of Needlestick/Sharps Injuries among Nursing and Midwifery Students in Arak, Iran. Iran J Epidemiol. 2011;7(3):58-64. [Persian].

30. Bahreini M, Bijani M, Rahmati H, Shahamat S. [The effectiveness of a multimedia training program on incidence of occupational exposure to contaminated sharp tools among nurses]. Iran Journal of Nursing. 2011;24(69):69-77. [Persian].

31. Gholami A, Salarilak S, Alinia T, Nejad Rahim R. [Study of Needle Stick Injuries among Health Care Workers at Teaching Hospitals in Uremia]. Iran J Epidemiol. 2010;6(3):57-61. [Persian].

32. Abdi M, Najafipour s, Hamidizade S, Jamali F, Pournoroz N. Survey of Accidental injuries caused by sharp instruments among the Jahrom university of medical sciences hospitals health care workers, 2008. J Jahrom Univ Med Sci. 2009;7(3):30-38. doi:10.29252/jmj.7.3.30.

33. Moradi AR, Mostafavi E, Moradi A. The prevalence and causes of needle stick injuries among the primary health care workers of Bahar city, Hamadan Province. Iran Occupational Health Journal. 2010;7(2):39-42. [Persian].

34. Jonaidi Jafari NA, Shasti $M$, Izadi $M$, Ranjbar $R$, Ghasemi $M$. Evaluation of frequency of Exposure to Medical Sharp Devices among Nurses of a University Hospital. J Mil Med. 2008;10(2):119128. [Persian].

35. Bijani B, Azimian J, Soleimany M, Mohammadi N. Epidemiology and risk factors of needle stick injuries among nurses in Bou-Ali Sina teaching hospital, Qazvin. Journal of Shahid Beheshti Nursing and Midwifery. 2013;22(78):1-9. [Persian].

36. Lotfi, R, Gashtasbi A. [Needle stick and sharps injuries and its risk factors among health center personnel (Astara; Iran, 2006)]. J Babol Univ Med Sci. 2008;10(4):71-77. [Persian].

37. Vahedi MS, Ahsan B, Ardalan M, Shahsavari S. Prevalence and Causes of needle stick injuries, in medical personnels of Kurdistan University's hospitals and dealing with such injuries due to contaminated sharp tools in 2003. Scientific Journal of Kurdistan University of Medical Sciences. 2006;11(2):43-50. [Persian].

38. Aghadoost D, Hajijafari M, Tabatabaei B, Ziloochi MH, Dalirian A. Occupational exposure to blood in the stuff of educational-medical centers of Kashan University of Medical Sciences in 2005. Feyz. 2007;10(4):59-64. [Persian].

39. Nasiri E, Mortazavi Y, Siamian H, Shaaban Khani B. The prevalence and study of the rate of needle stick injuries infected by blood in staffs of special departments of teaching and non teaching hospitals of Mazandaran province in 2003-2005. Iranian Journal of Infectious Diseases and Tropical Medicine. 2005;10(29):41-46. [Persian].

40. Askarian M, Malekmakan L. The Prevalence of needle stick injuries and its related factors among clinical dental students in Shiraz University of Medical Sciences, Iran. Kerman University of Medical Sciences Journal. 1383;12(4):265-270. [Persian].

41. Mirzaei T, Raveri A. Contact with contaminated needles and it's relation to recapping. Modern Care Journal. 2003;10(2):28-33. [Persian].

42. Afrasiabifar A, Salari M, Zarifi A, Mohebi Z. Skin penetrating injuries due to the insertion of sharp medical instruments contaminated with patients' blood or body secretion among the healthcare stuffs of Yasuj hospitals and the measures taken after injury, 2001. Journal of Yasuj University of Medical Sciences. 2003;7(28):17-23. [Persian].

43. Balouchi A, Shahdadi H, Ahmadidarrehsima S, Rafiemanesh H. The frequency, causes and prevention of needlestick injuries in nurses of Kerman: a cross-sectional study. J Clin Diagn Res. 2015;9(12):Dc1315. doi:10.7860/jcdr/2015/16729.6965.

44. Jahangiri M, Rostamabadi A, Hoboubi N, Tadayon N, Soleimani A. Needle Stick Injuries and their Related Safety Measures among Nurses in a University Hospital, Shiraz, Iran. Saf Health Work. 2016;7(1):72-77. doi:10.1016/j.shaw.2015.07.006.

45. Adib-Hajbaghery M, Lotfi MS. Behavior of healthcare workers after injuries from sharp instruments. Trauma Mon. 2013;18(2):75-80. doi:10.5812/traumamon.12779.

46. Mahmoudi N, Sepandi M, Sheikh Mohammadi A, Masoumbeigi H.
Epidemiological Aspects of Needle Stick Injuries among Nurses in a Military Hospital. Iranian Journal of Health, Safety \& Environment. 2015;2(3):374-379.

47. Mohammadnejad E, Nemati Dopolani F. Risk factors of needle stick and sharp injuries among health care workers. Journal of Nursing and Midwifery Sciences. 2015;2(1):34-39. doi:10.7508/ jnms.2015.01.005.

48. Gholami A, Borji A, Lotfabadi P, Asghari A. Risk factors of needle stick and sharps injuries among healthcare workers. Int J Hosp Res. 2013;2(1):31-38.

49. Farsi D, Zare MA, Hassani SA, et al. Prevalence of occupational exposure to blood and body secretions and its related effective factors among health care workers of three Emergency Departments in Tehran. J Res Med Sci. 2012;17(7):656-661.

50. Kazemi Galougahi MH. Evaluation of needle stick injuries among nurses of Khanevadeh Hospital in Tehran. Iran J Nurs Midwifery Res. 2010;15(4):172-177.

51. Parsa Pili J, Izadi N, Golbabaei F. Factors associated with needle stick and sharp injuries among health care workers. Int J Occup Hyg. 2013;5(4):191-197.

52. Rezaei S, Rabi Rad N, Tamizi Z, Fallahi Khoshknab M, Mohamad Nezhad E. An investigation into occupational hazards faced by nurses in paediatrics hospitals of Tehran University of Medical Sciences, 2006-2009. Int J Community Based Nurs Midwifery. 2013;1(4):200-207.

53. Ehsani SR, Mohammadnejad E, Hadizadeh MR, et al. Epidemiology of Needle Sticks and Sharp Injuries Among Nurses in an Iranian Teaching Hospital. Arch Clin Infect Dis. 2013;8(1):27-30. doi:10.5812/archcid.14409.

54. Mohammadi N, Allami A, Malek Mohamadi R. Percutaneous exposure incidents in nurses: Knowledge, practice and exposure to hepatitis B infection: Percutaneous exposure incidents in nurses. Hepat Mon. 2011;11(3):186-190.

55. Askarian M, Shaghaghian S, Gillen M, Assadian O. Body fluid exposure in nurses of Fars province, Southern Iran. Arch Iran Med. 2008;11(5):515-521.

56. Wilburn SQ, Eijkemans G. Preventing needlestick injuries among healthcare workers: a WHO-ICN collaboration. Int J Occup Environ Health. 2004;10(4):451-456. doi:10.1179/oeh.2004.10.4.451.

57. Ghanei Gheshlagh R, Fallahi Khoshknab M. Needle stick injuries, culture of silence: A Systematic Review. Journal of Health Promotion Management. 2015;4(1):31-50.

58. Yoshikawa T, Wada K, Lee JJ, et al. Incidence rate of needlestick and sharps injuries in 67 Japanese hospitals: a national surveillance study. PLoS One. 2013;8(10):e77524. doi:10.1371/journal. pone.0077524.

59. Voide C, Darling KE, Kenfak-Foguena A, Erard V, Cavassini M, Lazor-Blanchet C. Underreporting of needlestick and sharps injuries among healthcare workers in a Swiss University Hospital. Swiss Med Wkly. 2012;142:w13523. doi:10.4414/smw.2012.13523.

60. Ilhan MN, Durukan E, Aras E, Turkcuoglu S, Aygun R. Long working hours increase the risk of sharp and needlestick injury in nurses: the need for new policy implication. J Adv Nurs. 2006;56(5):563-568. doi:10.1111/j.1365-2648.2006.04041.x.

61. Kebede G, Molla M, Sharma HR. Needle stick and sharps injuries among health care workers in Gondar city, Ethiopia. Saf Sci. 2012;50(4):1093-1097. doi:10.1016/j.ssci.2011.11.017.

62. Martins A, Coelho AC, Vieira M, Matos M, Pinto ML. Age and years in practice as factors associated with needlestick and sharps injuries among health care workers in a Portuguese hospital. Accid Anal Prev. 2012;47:11-15. doi:10.1016/j.aap.2012.01.011.

63. Elmiyeh B, Whitaker IS, James MJ, Chahal CA, Galea A, Alshafi K. Needle-stick injuries in the National Health Service: a culture of silence. J R Soc Med. 2004;97(7):326-327. doi:10.1258/ jrsm.97.7.326.

64. Sangwan BR, Kotwal A, Verma AK. Occupational exposure to blood and body fluids amongst health care workers in a teaching hospital of the armed forces. Med J Armed Forces India. 2011;67(1):21-24. doi:10.1016/s0377-1237(11)80006-7. 